\title{
Circular economy and supply chain: a literature review
}

Renan Pereira1, Edivan Alexandre Ferreira' ${ }^{1}$ Josivan Leite Alves ${ }^{2}$, Jeniffer de Nadae', Graziela Darla Araujo Galvão ${ }^{3}$

${ }^{1}$ Department of Business Administration, Federal University of Cariri, Juazeiro do Norte, Ceará, Brazil.

${ }^{2}$ Department of Civil Engineering, Federal University of Cariri, Juazeiro do Norte, Ceará, Brazil.

${ }^{3}$ Production Engineering of Polytechnic School (University of São Paulo) São Paulo, São Paulo, Brazil

How to cite: Pereira, R., Ferreira, E.A., Alves, J.L. et al. (2020), “Circular economy and supply chain: a literature review", Brazilian Journal of Operations \& Production Management, Vol. 17, No. 04, 20201042.

https://doi.org/10.14488/BJOPM.2020.048

\section{ABSTRACT}

Goal: To analyze the publications on circular economy and supply chain using a systematic review of the literature and bibliometric analysis, the study was designed to answer the question: How is the international scientific production about Circular Economy and Supply Chain characterized? For such an answer it was found that the first published article was on the subject date from 2006 and 2013 there was a steady increase in the number of publications. Many publications mentioned the use of CE in the supply chain through the management of the green supply chain. The country with more publications about the area in the United Kingdom with 19,1\% of papers. Moreover, publications are generally about IT product and service supply chains.

Design/Methodology/Approach: Systematic literature review based on bibliometric theory and social network analysis, linking Circular Economy and Supply Chain.

Results: The articles do not point to studies on a specific supply chain, but only stress the importance of applying Circular Economy to the supply chain to mitigate the environmental impact of materials and products along with the flow from the production process to end consumers.

Limitations of the investigation: This paper contributes by analysing the international literature about the selected topics. In a future research agenda, this study could be applied to survey-based research to answer the research propositions suggested.

Practical implications: The research helps scholars to identify the main hot topics about Circular Economy and Supply Chain, main authors and papers. Also, can help managers to develop Circular Economy business models to improve and mitigate the environmental impacts on the production and supply chain.

Originality / Value: This research sheds light on controversies, discussed in the literature, concerning the effects linking Circular Economy and Supply Chain.

Keywords: Circular Economy; Supply Chain; Literature Review; Bibliometric Approach.

\section{INTRODUCTION}

In cases where development is sensitive to environmental issues, there is a recognition, to some extent, that there is a mismatch between what nature supports offering and what has been consumed by people (lizuka and Peçanha, 2014). The concept of Sustainability is growing stronger in public policies, as well as in academia and the industry (Geissdoerfer et al., 2017; Geissdoerfer et al., 2020).

Financial support: This work was supported by the National Counsel of Technological and Scientific Development (CNPq) and Cearense Foundation to Support Scientific and Technological Development (FUNCAP).

Conflict of interest: The authors have no conflict of interest to declare.

Corresponding author: jeniffer.nadae@ufca.edu.br

Received: 15 July 2020

Accepted: 09 October 2020

Editor: Osvaldo L. G. Quelhas 
It became increasingly important from debates on global warming and environmental concerns under increased human and industrial consumption, which led to the need of discussing alternatives to reduce environmental impacts. For Murray et al., (2017) a sustainable activity then is one that can be maintained for a long period without exhaustion, despite unforeseen events that may occur.

Global production of manufactured goods and services is based on a linear production model, characterized by a unidirectional flow in which raw materials are turned into end products and then discarded, which generates waste (Elia et al., 2017) and causes environmental impacts. Degradation of nature caused by the changes associated to this mode of production is intensified by the growth of the world population-the Ellen MacArthur Foundation (2013) estimates it will reach nine billion by 2050. Thus, concerns around sustainability arise from the need to undertake actions and efforts towards environmental preservation.

"We must understand that organizations, including companies, governments and nongovernmental organizations (NGO) will have to work in partnership so that there is this shift in paradigm, being that this is the business organizations biggest challenge" (Silva and Cândido, 2014), besides that integration between the social, economic, and environmental spheres has brought about a new approach: meeting the needs of current generations without compromising the future ones, and sustainability aims at reaching these three spheres simultaneously (Prugh and Assadourian, 2003). Seeking substantial improvement of the use of resources all around the economy, businesses began to look for ways to reuse products or their components and recycle materials and inputs to minimize environmental impact and produce more with less, whereas taking into account sustainability-related concerns (Bonciu and Bâlgăr, 2016; Ünal et al., 2019).

This gave rise to the Circular Economy (CE), an economic model opposed to the linear production model of take-make-waste, which generates significant amounts of waste. In this way, the circular economy model can help the deployment of sustainable strategies and the maximization of organizations (Geissdoerfer et al., 2017). This new way of managing the production chain arises as a strategy that aims at tackling the challenges of resource scarcity and waste management-a win-win approach from the economic value perspective (Bey et al., 2013; Homrich et al., 2018).

The CE model proposes economic growth dissociated from the consumption of resources and emission of pollutants. At the end of their life cycle, materials and products are conceived as resources, and not as waste. Thus, raw material cycles are closed, and waste, as well as demand for raw materials, is reduced (Elia et al., 2017). For Ellen MacArthur Foundation (2013), the $C E$ is an approach involving gradual decoupling of economic activity from the consumption of finite resources, taking waste out of the system-thus, redesigning the whole process so that waste is minimal, and all materials are reused. Therefore, a linear system is converted into a circular system when the connection is made between the use of resources and that of waste (Bilitewski, 2012).

The transition from a linear economic model to a CE benefits both the environment and the supply chain as a whole. In present conditions, production of goods in a supply chain wastes significant amounts of materials between the obtaining raw materials and the end of product manufacture, while in a CE, waste is mitigated (Bocken et al., 2016; Murray et al., 2017; Merli et al., 2018). To make the change from linear production to the circular mode possible, the supply chain must be adapted (Centobelli, et al., 2020).

Progress from a linear to a circular supply chain requires improved industrial design and efficient use of materials, reducing the flow of materials in manufacturing by using them in cascade-i.e. taking advantage of products and materials in ways different from those originally proposed, or turning them into resources for other industries (Schwab, 2014). According to Torres Junior and Parini (2017, p. 5)

"In the last decades, in parallel with the spread of CE concepts, green and sustainable practices of Supply Chain Management have been developed. They aim at integrating 
organizations' environmental concerns with practices aimed at minimizing the involuntary negative consequences of production and consumption processes".

Broadly speaking, a supply chain comprises activities related to the flow and transformation of products-from the extraction of raw material to the arrival at the hands of the consumer-as well as to the respective information flows (Ballou, 2006). Thus, the supply chain encompasses all movement involved in the manufacture of a product, from obtaining raw materials, storing and transformation into the end product, to its transportation and distribution, in addition to the informational flow.

For Christopher (1997), however, the supply chain is a network of interconnected and interdependent organizations working in cooperation to control, manage, and improve the flow of materials and information from suppliers to final users. The author states that the word "chain" should be replaced by the term "network", due to the great number of suppliers and customers involved in the process.

Aiming at a more in-depth study of $C E$, this paper endeavors to identify international publications on circular economy and supply chain to understand how the subject is approached by researchers in the field, as well as to contribute disseminating the concepts in this field of study, a relatively new one, particularly for scholars in Brazil.

In the context of this discussion, the study was designed to answer the following question: How is the international scientific production about Circular Economy and Supply Chain characterized? Therefore, the objective of this paper is to analyze the publications on circular economy and supply chain using a systematic review of the literature and bibliometric analysis.

To meet this objective, this paper is divided into five sections. The first contextualizes the subject and presents the research problem and objective. Section 2 is a brief presentation of concepts and the research method. The stages of the search in the Scopus database, software, and analysis networks are presented in section 3. Section 4 comprises results and discussion of the theme, and section 5 , the conclusions.

\section{THEORETICAL FRAMEWORK}

\section{Circular Economy and Supply Chain}

The concept of Circular Economy (CE) was developed in 1990, initially by British authors Pearce and Turne. Their 1990 article "Economics of natural resources and the environment" was the first to approach the subject systematically. According to Geng and Doberstein (2008), the concept of CE is based on the idea that the economy and the environment can have a healthy coexistence. According to Abadia et al. (2016), this concept is still very recent and not consolidated.

The Ellen MacArthur Foundation (2015) lists some of the features of circular economy and the problems it aims at mitigating:

- The industry becomes restorative;

- $\quad$ It intends to use renewable energy;

- It minimizes, tracks down, and eliminates the use of toxic chemicals; and

- $\quad$ It designs out waste.

Corroborating with this idea, for Ribeiro and Kruglianskas (2014), "CE proposes that materials be utilized in such a way as to maximize their value, reducing waste and creating economic benefits along with environmental benefits." Both authors expound on the added value products may have if, instead of single use, they maximize their effects and benefits through collective use. The main focus of EC for Sehnem and Pereira (2019) is the intelligent use of resources that are already in use in the production process so that economic growth is not exclusively dependent on the growing consumption of new resources.

Thus, CE stands by the need for a "functional service" model in which manufacturers or retailers increasingly preserve the property of their products and, whenever possible, act as 
service renderers-selling the use of products and not their unidirectional consumption (Ellen MacArthur Foundation, 2015). If an economy of unitary and personal consumption is no longer used, the property of an item is unique, whereas it can be used by several individuals who contribute to the generation of new businesses, providing the basis for collective consumption (Botsman and Rogers, 2009; Bonciu and Bâlgăr, 2016).

Great advances have been made in comparison with the linear economy model, based especially on the reduction of costs in large industries. However, efforts are still not sufficient to end waste and vary by the mode of operation, whether or not it is ecological and meets basic CE principles. For the Ellen MacArthur Foundation (2015), any system based on consumption and not in the restorative use of resources implies significant losses along the entire value chain. The end of wastage is one of the chief features of CE. According to the (Bocken, 2015), in the production of goods, significant amounts of materials are usually lost in the chain between mining and final manufacture.

Still, according to (Niero et al., 2016), this economic paradigm is opposed to the current take-make-dispose-source linear model, which generates a significant amount of waste. For the implementation and use of $\mathrm{CE}$, efforts at several levels-micro, medium, and macro-are required. At the micro-level, in the area of production, factories and agricultural products are encouraged or forced to adopt a cleaner production and an ecological project (Su et al., 2013). Implementation at the micro-level allows products to be useful again in the supply chain, as corroborated by (Nasir et al., 2017) regarding the implementation of circular economy practices that foster the design of circular or reverse supply chains, allowing products at the end of their life cycle to re-enter the supply chain as a production input through recycling, reuse or remanufacture.

The efforts at the medium, or regional, level aim at the development of more sustainable agriculture and environments. According to Su et al., (2013), practices include the development of eco-industrial parks and an eco-agricultural system. At the macro-level, this work is concerned with cities, regions, and countries. According to Su et al., (2013), at the macro level (city or regional scale), more complex and extensive cooperative networks between industries and industrial parks of the primary, secondary, and tertiary sectors emerge in the production area.

Besides contributing to environmental preservation, the adoption of CE brings about benefits to the supply chain. Advantages for the economy are the reduced use of materials and energy, better mitigation of volatility and supply risks and higher multipliers, due to lower sectorial changes and externalities. Businesses will create new profit and competitive advantage groups, improving their resilience against some of the present strategic challenges and expanding, based on their respective initial situations. Finally, advantages to consumers include the availability of more options, fewer problems related to premature obsolescence and higher quality of service and secondary benefits (Bonciu and Bâlgăr, 2016).

Ballou (2006) defines supply chain as a set of functional activities (transportation, inventory control, etc.) that are repeated numerous times along the channel through which raw materials are converted into finished products with added value for the consumer. It is represented by the entire journey of raw materials until they are converted into end products and their consequent arrival at the hands of the consumer, in addition to all the information created and distributed along with this flow. The supply chain comprises all stages directly or indirectly involved in supplying the demand of a customer, such as suppliers, manufacturers, transporters, warehouses, distributors, retailers and the customer himself, besides renderers of technical assistance or any other agent representing stages of the goods and services production and commercialization process (Chopra and Meindl, 2003).

Thus, by supply chain management (SCM), we mean the activities aiming at interconnecting these stages to reach desired goals (Barbieri et al., 2014). For Lambert et al., (1998), SCM is 
"The integration of business processes from final users to the original suppliers who provide products, services, and information that add value for consumers" (Lambert et al., 1998, p. 504).

Besides creating greater economic for industries, this integration helps to reduce environmental impact, as

\begin{abstract}
"The increasing influence of sustainability in the management of the supply chain and in operational practices can also be attributed to the fact that, besides the growing demands for strong economic performance, organizations are now tasked with an environmental and social performance by the main actors, stakeholders" (Torres Junior and Parini, 2017, p. 5).
\end{abstract}

Thus, due to systematic environmental concerns in the supply chain management, the area concerned with the environmental aspect of the supply chain is given a new name, Green Supply Chain Management (GSCM) (Barbieri et al., 2014). The GSCM integrates environmental thinking and conventional SCM, such as product design, selection of materials and suppliers, production processes, delivery of end products to consumers and management of the end of products' useful life (Srivastava, 2007). The concepts of Green Supply Chain Management or Sustainable Supply Chain Management were developed in parallel with the CE rationale, so the integration of CE principles within sustainable supply chain management offers clear advantages from the environmental perspective (Genovese et al., 2017).

Thus, aligning supply chain strategies with CE principles has become important for environmental sustainability (Mcdonough and Braungart, 2010; Pauli, 2010). The principles of CE reveal a desire to extend the limits of sustainable supply chain practices based on the paradigm of continuous resource circulation within a closed system, thus reducing the need for new raw material inputs into production systems (Genovese et al., 2017). This model has encouraged companies operating in the same supply chain to participate in sustainable activities (Torres Junior and Parini, 2017). This encouragement presupposes understanding CE benefits for supply chain management, using the latter to achieve its main objective-to increase the profits for organizations and becomes an efficient and promising means of reaching its goal without environmental damage.

\title{
METHOD
}

Given the aim of this study, a systematic review of the literature (SRL) was conducted to help answer the research question: How is the international scientific production about Circular Economy and Supply Chain characterized? To obtain an overview of the literature on the topic, the Scopus database was consulted. It is considered the largest database of abstracts and citations of peerreviewed literature: scientific journals, books and congress proceedings (Scopus, 2018).

The procedures were organized according to the stages of the Littell et al., (2008) research protocol, following three stages: data collection, data analysis, and synthesis. (Tranfield et al., 2003).

Data collection was conducted in May 2018, and the search terms used were: "circular economy" AND "supply chain". The database then selected the titles, abstracts, and keywords containing these terms, which resulted in 185 articles. The final base, selecting only articles in Portuguese and English, comprises 90 articles (Table 1).

Table 1 - Database search criteria

\begin{tabular}{ccc}
\hline Selected topics & Stages & $\#$ \\
\hline Title, Abstract and keywords & "circular economy"AND "supply chain" & $\mathbf{1 8 5}$ \\
Type of document & Article & $\mathbf{1 7 7}$ \\
Language & English and Portuguese & $\mathbf{9 0}$ \\
\hline & Final base & $\mathbf{9 0}$ \\
\hline
\end{tabular}

Source: Authors 
After selection of the articles, the data were analyzed aggregating bibliometric analysis and a systematic review of the literature.

The network analysis was conducted using the VosViewer software, used for construction and visualization of bibliometric networks. These data are generated through databanks, of which Scopus is an example, which relates and couples bibliographical and thematic citations about a given subject (Vosviewer, 2019).

Using the databank, a descriptive analysis was carried out, generating graphics-using Excel and Minitab software-of countries with more publications on the topic, evolution of research over the years, main journals publishing on the topic, most quoted authors, and outliers with total citations per author.

Analysis of keywords is useful to evince the concepts associated with the research question, adding consistency to the conceptual discussion of sustainable development and performance indicators associated to this subject. After that, content analysis was carried out based on reading of the abstract and of the last session of each article, how discussions, conclusions and results (Locke and Golden-Biddle, 1997).

Finally, the bibliometric synthesis was done. According to Crossan and Apaydin (2010), it is in this step that the greatest value is added to bibliometric analysis, since at this stage new knowledge is created based on complete and exhaustive analysis of data.

\section{RESULTS}

The publications included in the Scopus database using the keywords "Circular Economy" and "Supply Chain" returned 90 publications over a period of 13 years. The first publications came out in 2006: "Sustainable Supply Chain Networks - A New Approach for Effective Waste Management" and "Strategic Green Supply Chain Based on Circular Economy - A New View for Sustainable Manufacturing in China", published in the Wuhan Ligong Daxue Xuebao/Journal of Wuhan University of Technology and WIT Transactions on Ecology and the Environment magazines respectively.

The two texts deal with the strategies provided by China for the development and review of the literature with empirical research about the movement toward sustainability, concluding that this is only possible by means of actions integrating economic and ecological movements.

Only in 2016 did this number increase considerably and kept on growing. An interesting fact is that, in the first half of 2018, the year in which this research was carried out, the number of publications on the circular economy had already surpassed by more than $50 \%$ of those published in 2017, as shown in Figure 1.

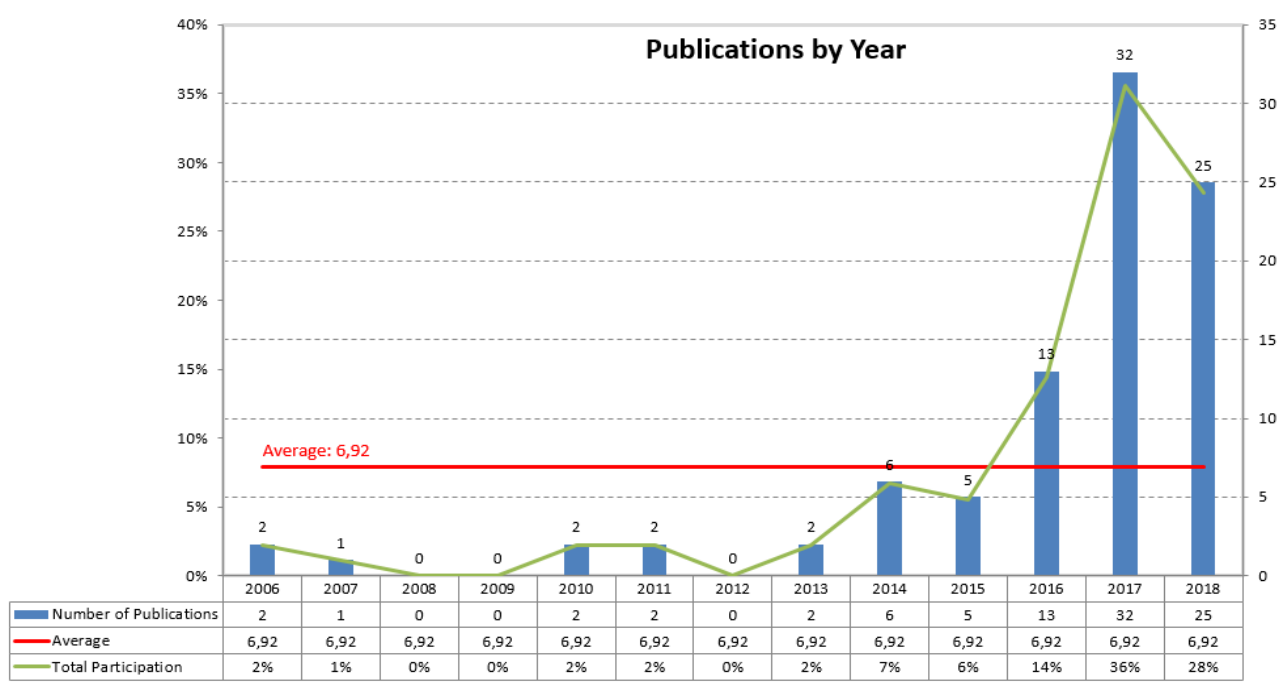

Figure 1 - Publications per year Source: Authors 
Still talking about the development of the theme, a search in the same database with the same parameters, it is possible to realize that interest in the circular economy is increasing, while related studies related to supply chain until 2012, is not precise. After 2013 the theme comes an increase in the interest of the academy. This number is shown in Figure 2.

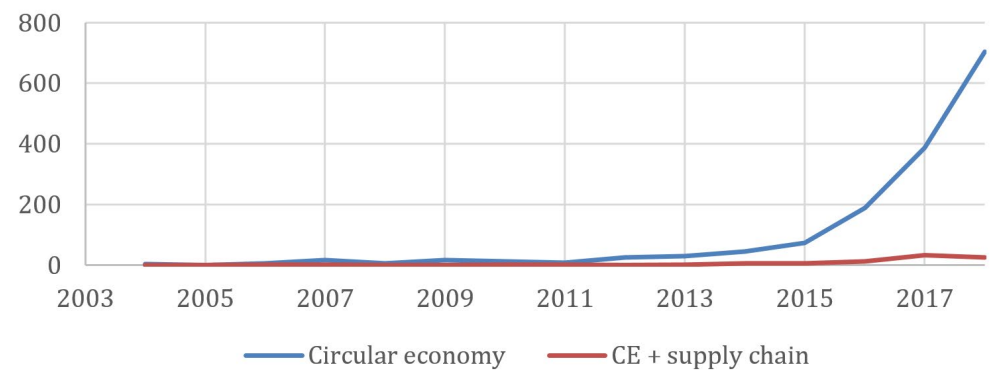

Figure 2 - Publications per theme Source: Authors

Starting from the discussion of strategies for CE implementation in the Supply Chain, created by China for development, articles from 2006 to 2013 describe an ascending curve of knowledge about CE in its various aspects. The authors created studies reviewing the literature about movements towards sustainability, in addition to identifying direct and indirect impacts of environmental regulations.

Besides the aforementioned Chinese strategies, other contributions to this reality were programs adopted by the European Union from 2014 onwards under the title "Towards a Circular Economy - A Zero Waste Programme for Europe", and by China itself, with its Circular Economy Promotion Bill, approved in 2009.

Proceeding with the analysis, in 2010, the authors dealt with the balance between economic growth and environmental management, using Chinese enterprises as a focus for these studies and analyzing how the country's companies collaborate with environmental protection using CE.

The year of 2011 was marked by texts describing CE concepts to build a closed production model, examining the role of CE practices and the influences of implementing these practices on these companies' improved performance. In 2012, there were no publications on the subject analyzed; however, 2013 begins a period of increase in publications.

The conceptualization of a CE and a rating system marks the studies conducted in 2013 about the unification of ideas that permeate the trend towards supply chain management from the standpoint of the industrial production chain links.

From 2013, an increased growth is observed in the number of studies, whereas 2017 is outstanding, with $36 \%$, as well as 2018 , when up to the month of May $28 \%$ of publications dealt with the subject. From 2014 to 2016, publications dealt with supply chain management via CE, particularly contemplating information management technologies aiming at cleaner production, in addition to experimentation with materials that can be utilized through combined elements, with innovative recycling that does not affect the quality of the remanufactured product.

Comparing 2017 with 2016, there is a $246 \%$ growth, the same average growth seen in 2016 concerning 2015. In 2017, 32 articles were published, which accounts for the highest point in the chart. In 2018, up to the moment of data collection, 25 articles had been published.

Although the analysis used articles published in 2018 even though the fact that the year had not ended, the studies of this year deal with warnings caused by global warming, the consequence that the current production model, linear economy, must address towards a production model that meets CE objectives, helped by the supply chain and reverse logistics.

Figure 3 analyzes the countries where publications originated. Great Britain has 25 publications listed, corresponding to $19 \%$ of total publications concerning CE and supply chain, followed by the United States, which accounts for $10 \%$, or 13 publications, and by China and the Netherlands, with $8 \%$ each. This amounts to an average of 11 publications per country on the subject, followed by the 
remaining countries, with an average of $2 \%$ each, or around 2 articles per country. Brazil is responsible for $1 \%$ of articles published. The reason why the UK and China have a greater number of publications may be because the two countries have specific EC laws. Still, USA and UK were the countries cradle of supply chain studies (Humphrey and Memedovic, 2006).

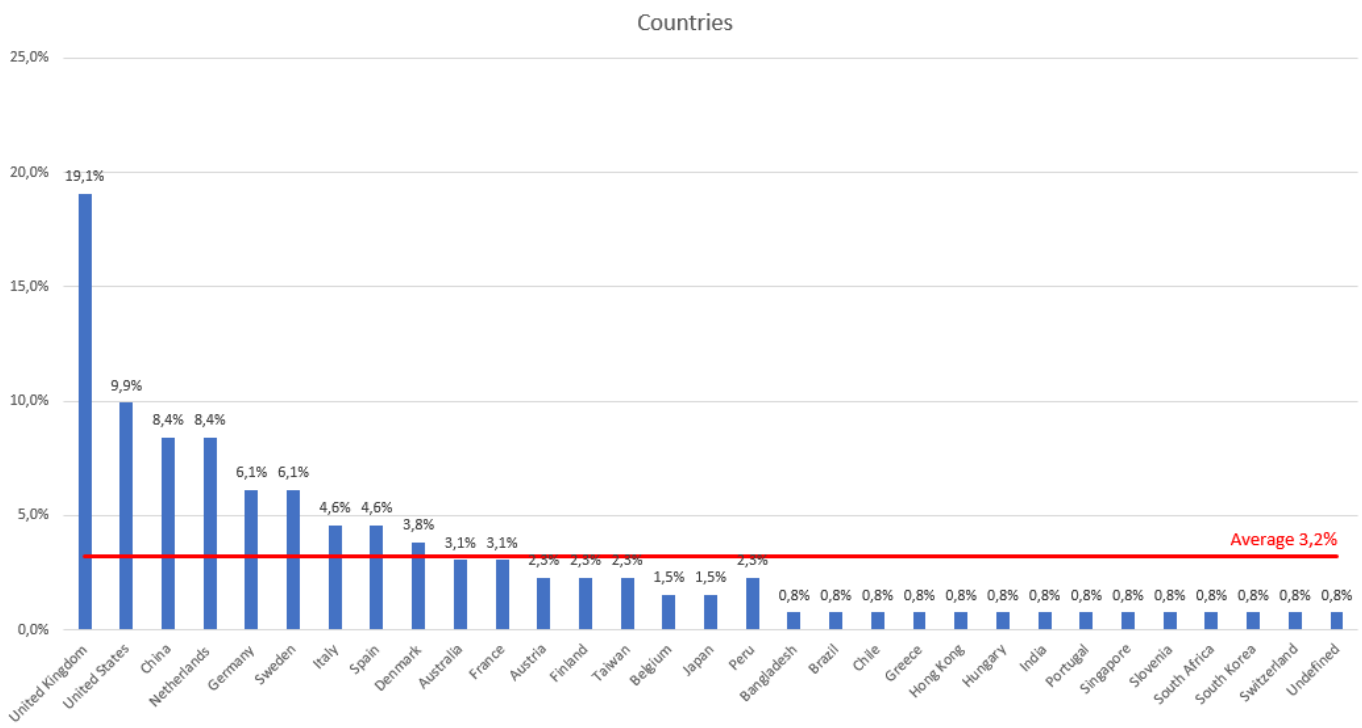

Figure 3 - Publications per country Source: Authors

The 235 papers from the database were classified in 18 Scopus areas, as shown in Figure 4. It should be noted that, since articles can be classified under more than one subject area, the amount of publications is different from the number of articles in the database.

About 27\%, or 63 articles, are in the field of Environmental Science. Engineering answers for almost half of this number, with $16 \%$ of publications, followed by Energy, with $15 \%$ of publications. There is still a greater difference between the aforementioned areas and the remainder, which averages out to $3 \%$ of publications, or nearly seven articles per area.

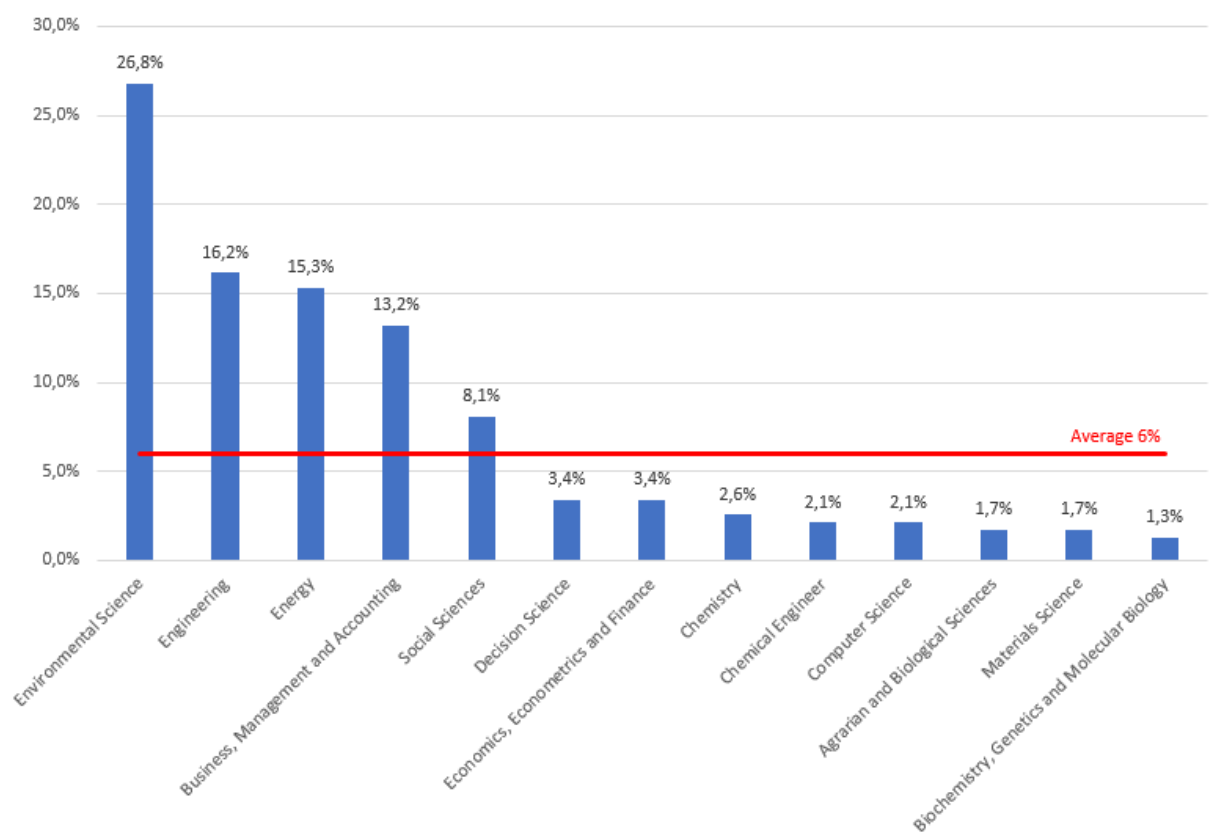

Figure 4 - Thematic areas of publications Source: Authors 
Table 2 shows the journals with at least three articles published on the topic and their Impact Factor. Impact Factor (IF) is a measure of the frequency with which the average article of a journal was quoted in a certain year. It is used to gauge the importance or classification of a journal calculating the frequency with which articles are cited. Calculation is based on two years and consists in dividing the number of times articles have been cited by the number of quotable articles (Research Guides, 2018).

It can be seen that the journal Journal of Cleaner Production has the most publications on the subject, with a total of 20 articles. The scope of this journal is research and practice of Cleaner Production, which is the type of production that aims at avoiding waste while increasing efficient use of energy, water, resources, and human capital.

The Sustainability magazine emphasizes environmental, cultural, economic, and social sustainability of human beings and presents seven publications on the subject. However, it has less impact than other journals. The Journal of Industrial Ecology expounds on industrial metabolism, technological change, dematerialization and decarbonization, life cycle planning, design and evaluation, environmental design, product management, industrial symbiosis, environment-aimed products and eco-efficient policy, and has presented four publications on the subject.

The following three journals include three publications each on the subject: ACS Publications proposes studies about sustainability in the chemical industry and advances in Green Chemistry and Green Engineering. This journal has the greatest Impact Factor compared to the others. The International Journal of Production Research focuses on productive chains and their innovations, as well as on the area of logistics.

The Resources, Conservation and Recycling magazine addresses the transformation processes involved in a transition to more sustainable production and consumption systems. The Science of the Total Environment magazine focuses on studying the total environment, which is the union of atmosphere, hydrosphere, biosphere, lithosphere, and anthroposphere.

Table 2 - Journals

\begin{tabular}{ccc}
\hline SOURCE TITLE & \#ARTICLES & IF \\
\hline Journal Of Cleaner Production & 20 & 5.715 \\
\hline Sustainability Switzerland & 7 & 1.789 \\
\hline Journal Of Industrial Ecology & 4 & 4.123 \\
\hline ACS Sustainable Chemistry And Engineering & 3 & 5.951 \\
\hline International Journal Of Production Research & 3 & 2.325 \\
\hline Resources Conservation And Recycling & 3 & 3.313 \\
\hline Science Of The Total Environment & 3 & 4.900 \\
\hline
\end{tabular}

Note: Only journals with three or more publications on the subject were selected.

Source: Authors

Table 2 shows the list of journals and the respective number of publications, besides their Impact Factor (IF). It must be noted that, although it contains only three publications, the journal ACS Sustainable Chemistry and Engineering has a greater Impact Factor than the one with the largest number of publications, which shows its relevance to the subject.

Analyzing the total citations of the articles in the selected database, Figure 5 tries to determine which authors are considered outliers, a concept used to define the relationship between citations between authors and their respective number of citations in other articles. The articles in the sample were quoted 10.05 times on average, but some are above average, and five others are considered extreme outliers for having 35 or more citations. Table 3 presents the details of these articles. 


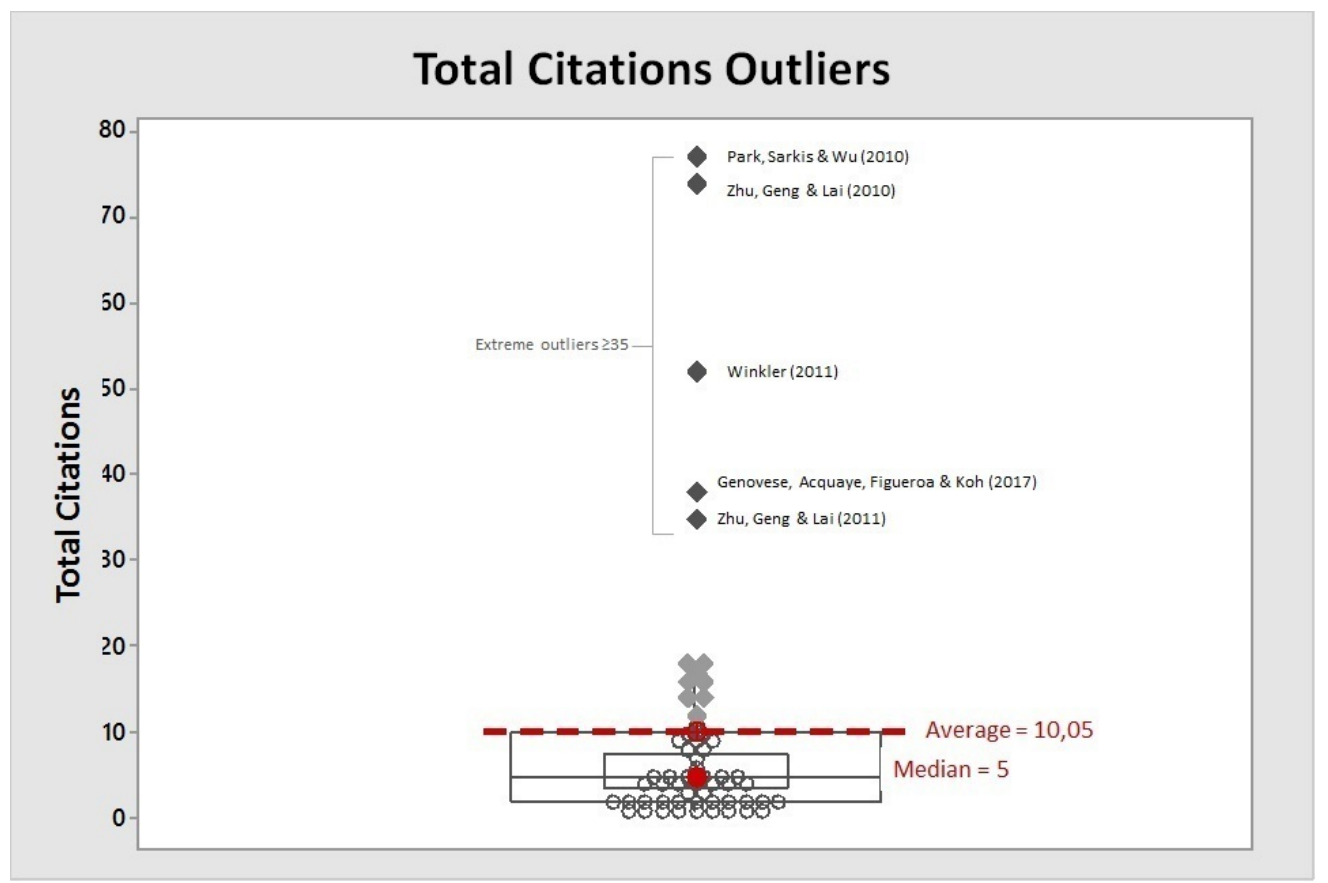

Figure 5 - Total Citations Outliers

Source: Authors

Based on Figure 5 and aiming at understanding the subjects under debate, the systematic reading consisted in a thorough reading of the works of the top five cited authors, besides analyzing these works to find out which were the most relevant topics raised by the authors and the methods they used, summarize in Table 3.

Table 3 presents the authors, objectives, method and number of citations of each publication. It deserves notice that three of the five articles examine Chinese enterprises using the case study method. Overall, the articles attempt to relate sustainability practices to supply chain management in order to minimize environmental impact, in line with the CE concept.

Criteria were defined for the production of Table 4, namely: the article must have analyzed some kind of industry, which should have been the subject of at least two articles concerned with the supply chain, and the article in question must define the type of supply chain under analysis. Furthermore, the article should not consist of a simple review of literature, but in a survey or case study.

Table 4 shows that after applying the filter to the first 90 articles, only 55 fit the preestablished criteria. Among these, the construction and manufacture sectors were the most studied through of case studies. Together, these areas account for more than half of the articles analyzed using the case study method.

Regarding supply chain analyses, it must be noted that the authors tend to focus on an environmental analysis of the supply chain, whereas some use green supply chain concepts, which take into account the environment as a relevant variable. Additionally, the GSC concept is similar to that of CE.

In bibliometric research, mapping by keywords and most used terms can shed light on the topic and help researchers define study topics (Alvarado, 1984). The VOSViewer software offers several graphic analyses based on the joint occurrence of the items analyzed (van Eck and Waltman, 2010). The system shows the connection between related terms and authors, allowing their breakup into groups called clusters. Each cluster is represented by a color and aggregates all items considered similar. The size of the circles in the maps denotes the number of occurrences of the item, whereas the proximity between two items shows their degree of relation - the nearer they are, the more related to each other (van Eck and Waltman, 2010). 
The more important an item, the larger it is in writing and the larger its representative circle (van Eck and Waltman, 2010). According to Figure 6, the top keywords are circular economy and sustainability, followed by supply chain and recycling. The keyword network has six clusters.

Table 3 - Extreme outliers of the sample

\begin{tabular}{|c|c|c|c|c|c|}
\hline 峞 & $\begin{array}{l}\mathscr{n} \\
\text { 웅 } \\
\frac{1}{5} \\
\frac{2}{4}\end{array}$ & 岂 & $\begin{array}{l}\text { 岁 } \\
\text { 岗 } \\
\text { ○ }\end{array}$ & $\begin{array}{l}\text { 음 } \\
\text { 오 } \\
\text { 岌 }\end{array}$ & $\begin{array}{l}\frac{n}{2} \\
\text { 을 } \\
\frac{E}{U} \\
=\end{array}$ \\
\hline 2010 & Park, J. Sarkis, J. Wu, Z. & $\begin{array}{c}\text { Creating integrated } \\
\text { business and } \\
\text { environmental } \\
\text { value within the } \\
\text { context of China's } \\
\text { circular economy } \\
\text { and ecological } \\
\text { modernization. }\end{array}$ & $\begin{array}{l}\text { To examine and } \\
\text { highlight how the } \\
\text { Information Technology } \\
\text { (IT) sector should } \\
\text { respond to the } \\
\text { emergent CE } \\
\text { regulations and how IT } \\
\text { companies should } \\
\text { position themselves in } \\
\text { this new business } \\
\text { environment to create } \\
\text { higher value for their } \\
\text { stakeholders. }\end{array}$ & $\begin{array}{c}\text { Case studies in three } \\
\text { enterprises in the } \\
\text { Information Technology (IT) } \\
\text { and electronics industries in } \\
\text { China. }\end{array}$ & 77 \\
\hline 2010 & Zhu, Q. Geng, Y. Lai, K.-H. & $\begin{array}{l}\text { Circular economy } \\
\text { practices among } \\
\text { Chinese } \\
\text { manufacturers } \\
\text { varying in } \\
\text { environmental- } \\
\text { oriented supply } \\
\text { chain cooperation } \\
\text { and the } \\
\text { performance } \\
\text { implications. }\end{array}$ & $\begin{array}{l}\text { To investigate whether } \\
\text { Chinese manufacturers, } \\
\text { who diverge regarding } \\
\text { Environmental Supply } \\
\text { Chain Cooperation } \\
\text { (ESCC), will implement } \\
\text { CE practices differently. }\end{array}$ & $\begin{array}{l}\text { Measurement based on a } \\
\text { review of the literature and } \\
\text { on field interviews, which } \\
\text { were organized in a } \\
\text { research questionnaire to } \\
\text { evaluate theoretical } \\
\text { constructions. }\end{array}$ & 74 \\
\hline 2011 & Winkler, H. & $\begin{array}{l}\text { Closed-loop } \\
\text { production systems. } \\
\text { A sustainable supply } \\
\text { chain approach. }\end{array}$ & $\begin{array}{l}\text { To outline the concept } \\
\text { of sustainable supply } \\
\text { chain networks (SSCN) } \\
\text { as a suitable means of } \\
\text { designing closed-cycle } \\
\text { production systems. }\end{array}$ & $\begin{array}{l}\text { Literature and formal } \\
\text { empirical research. }\end{array}$ & 52 \\
\hline 2017 & $\begin{array}{l}\text { Genovese, A., Acquaye, A. } \\
\text { A., Figueroa, A., Koh, S. C. L. }\end{array}$ & $\begin{array}{l}\text { Sustainable supply } \\
\text { chain management } \\
\text { and the transition } \\
\text { towards a circular } \\
\text { economy: Evidence } \\
\text { and some } \\
\text { applications. }\end{array}$ & $\begin{array}{l}\text { To verify the potential } \\
\text { improvement of } \\
\text { sustainable supply chain } \\
\text { management practices, } \\
\text { aligning them with } \\
\text { circular economy } \\
\text { concepts. }\end{array}$ & $\begin{array}{l}\text { Case-based approach } \\
\text { (adopting examples from } \\
\text { the chemical and foodstuffs } \\
\text { industries). The study } \\
\text { examined the } \\
\text { environmental implications } \\
\text { of the implementation of } \\
\text { circular production systems, } \\
\text { affording a comparison with } \\
\text { traditional linear production } \\
\text { alternatives. }\end{array}$ & 38 \\
\hline 2011 & Zhu, Q. Geng, Y. Lai, K.-H. & $\begin{array}{l}\text { Environmental } \\
\text { supply chain } \\
\text { cooperation and its } \\
\text { effect on the circular } \\
\text { economy practice- } \\
\text { performance } \\
\text { relationship among } \\
\text { Chinese } \\
\text { manufacturers. }\end{array}$ & $\begin{array}{l}\text { To introduce the CE } \\
\text { concept to foster } \\
\text { economic development } \\
\text { and, at the same time, } \\
\text { to lower environmental } \\
\text { and resource } \\
\text { challenges. }\end{array}$ & $\begin{array}{c}\text { Using data from surveys } \\
\text { collected from } 396 \text { Chinese } \\
\text { manufacturers. Analyses are } \\
\text { done through hierarchical } \\
\text { regression. }\end{array}$ & 35 \\
\hline
\end{tabular}

Source: Authors 
Table 4 - Analysis of the sample

\begin{tabular}{|c|c|c|c|}
\hline & & \#ARTICLES & FI \\
\hline \multirow{3}{*}{ 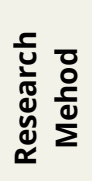 } & Survey & 48 & $59 \%$ \\
\hline & Study Case & 30 & $37 \%$ \\
\hline & Ambos & 4 & $5 \%$ \\
\hline \multirow{3}{*}{ 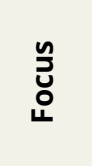 } & Supply Chain (SC) & 42 & $60 \%$ \\
\hline & Green supply chain (GSC) & 25 & $36 \%$ \\
\hline & $\mathrm{SC}+\mathrm{GSC}$ & 3 & $4 \%$ \\
\hline \multirow{11}{*}{ 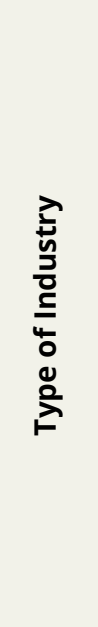 } & Manufacturing Industry & 9 & $16 \%$ \\
\hline & Food & 7 & $13 \%$ \\
\hline & Chemical & 8 & $15 \%$ \\
\hline & Bioenergy & 4 & $7 \%$ \\
\hline & Automobile & 4 & $7 \%$ \\
\hline & Construction & 11 & $20 \%$ \\
\hline & Electronic & 3 & $5 \%$ \\
\hline & Energy & 3 & $5 \%$ \\
\hline & Textile & 2 & $4 \%$ \\
\hline & Aluminium & 2 & $4 \%$ \\
\hline & Stell & 2 & $4 \%$ \\
\hline
\end{tabular}

Source: Authors

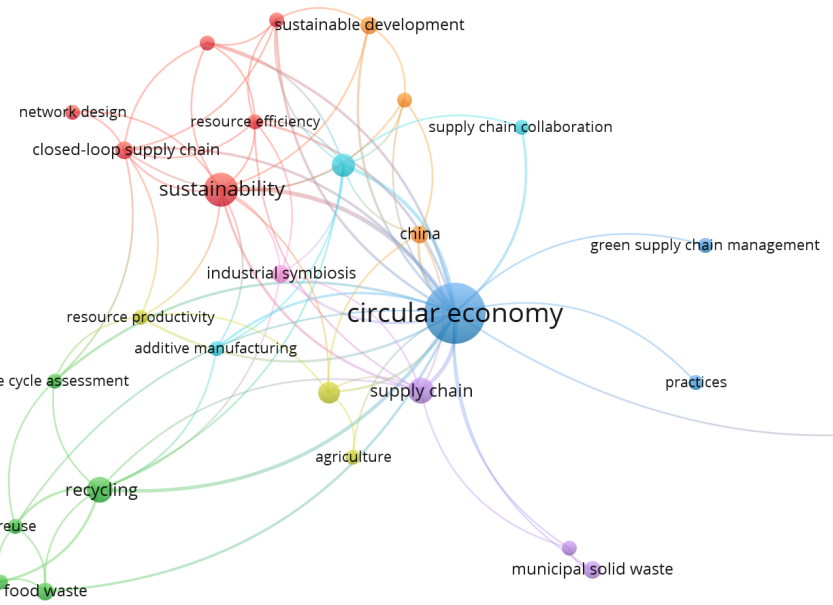

\section{象 VOSviewer}

Figure 6 - Co-occurrence of authors' keywords. Note: This network was drawn up using restriction criteria of at least two occurrences by the VosViewer software using extracts from the database. The total strength of the joint occurrence links will be calculated for each of the 29 keywords. Twenty-nine of the 208 keywords meet the threshold.

$$
\text { Source: Authors }
$$

A map of the terms demonstrates the structure of a scientific field, showing the relation between relevant terms of the area. During term selection, the main study field topics are 
verified and the relation of the terms with these topics to identify their relevance in differentiating each article (van Eck and Waltman, 2010).

Keywords are grouped in six clusters and the occurrences are presented in Table 5.

Table 5 - Keyword occurrence

\begin{tabular}{|c|c|c|c|c|}
\hline Clusters & Keywords & Occurrences Clusters & Keywords & Occurrences \\
\hline \multirow{9}{*}{1} & Circular Economy & 32 & Recycling & 6 \\
\hline & Industrial Ecology & 5 & Food Waste & 3 \\
\hline & China & 3 & Life Cycle Assessment & 2 \\
\hline & Sustaintable Development & 3 & Reuse & 2 \\
\hline & Additive Manufacturing & 2 & Insects as Feed & 2 \\
\hline & Supply Chain Management & 2 & Supply Chain & 6 \\
\hline & Supply Chain Collaboration & 2 & Municipal Solid Waste & 3 \\
\hline & Green Supply Chain Mangement & 2 & Business Model & 2 \\
\hline & Pratice & 2 & Manufacturing & 4 \\
\hline \multirow{7}{*}{2} & Sustainability & 10 & Resource Productivity & 2 \\
\hline & Closed-Loop Supply Chain & 3 & Agriculture & 2 \\
\hline & Industrial Symbiosis & 3 & Manufacturing Industry & 2 \\
\hline & Resource Efficiency & 2 & Green Supply Chain & 2 \\
\hline & Business Model Innovation & 2 & & \\
\hline & Product-Service Systems & 2 & & \\
\hline & Network Desing & 2 & & \\
\hline
\end{tabular}

Source: Authors

As they are related to cluster 1, the concepts of "CE", "supply chain management", and "collaboration in the supply chain" form the basis for sustainable management of the green supply chain, which is important for strategies to achieve environmental advantages. Another place where this cluster occurs is China, one of the world's major industrial hubs, which is committing to improve its environmental performance by developing methods and techniques to minimize environmental impacts.

Cluster 2 includes a set of publications correlated to the CE concept, defined mainly by the efficiency of resources that a closed supply chain can afford, allying network design, industrial symbiosis and sustainable services, and product systems (Genovese et al., 2017).

Foodstuff waste and the existence of chemical surpluses after industrial processing have been aggravating, and because of this fact, the authors in cluster 3 use CE notions to promote reutilization of resources that are still being used, recycling everything possible to obtain a positive life cycle evaluation.

Since municipalities are the most significant sources of solid waste, the studies in cluster 4 address supply chain expertise given regulations in force and use the CE context for proper management of this waste, applying a business model structured to optimize this situation.

The supply chain is directly related to productivity in agriculture, as shown in cluster 5 , which analyzes the relationship between governance and water treatment to foster cultivation, which is a strong element in the promotion of monocultures.

The authors in cluster 6 , on the other hand, discuss green supply chain strategies based on the concept of the circular economy in industrial operations, examining the application of the CE model in sustainable operations.

The articles do not point to studies on a specific supply chain, but only stress the importance of applying CE to the supply chain to mitigate the environmental impact of materials and products along with the flow from the production process to end consumers.

\section{CONCLUSION}

This paper aimed to analyze the publications about circular economy and supply chain. With this objective, a systematic review of the literature and bibliometrics was carried out, 
searching for articles with the terms "circular economy" and "supply chain" in the Scopus database.

The first publications on the subject date from 2006, and there were periods without any publication on the topic. From 2013 onwards, there was a steady increase in the number of publications.

As expected, many publications mentioned the use of CE in the supply chain through management of the green supply chain, a topic also mentioned by some of the authors in section 2 of this article.

It was expected that some supply chains be given prominence and that authors would be able to identify, through their research, which supply chains, of which product, employed the most sustainable actions and the CE model. However, it was impossible to obtain this information from the database, and thus no supply chain was analyzed with greater frequency. Most studies analyze IT product and service supply chains.

The articles in the database were cited 10.05 times, on average, and five authors stood out for having 35 or more citations: Park et al., (2010); Zhu et al., (2010); Winkler (2011); Genovese, et al., (2017); and Zhu, et al., (2011). These authors are considered extreme outliers in the sample, as they are much above the average number of citations. Three of these studies were drawn up in China, which appears in the keyword network. However, Great Britain is the country with most publications (around 19\%). Thus, it is clear that China has been the site of studies on the subject and is outstanding for the number of citations of the articles published there, although it is not the country with the most publications on the subject.

The area with the largest number of publications is that of Environmental Science, with about $27 \%$ of the articles. This significant number of publications is explained by the topic, which involves the reduction of environmental impact caused in production.

The journal with the most publications is the Journal of Cleaner Production, with 20 articles analyzed. However, the journal ACS Sustainable Chemistry and Engineering, which published only three articles, has a higher Impact Factor than the Journal of Cleaner Production. The Impact Factor measures the frequency with which the average article of a journal was cited in a given year.

We used only the Scopus database. Other bases could be used, such as Web of Science. A more in-depth analysis of Brazilian studies could also be drawn up and added to this survey.

Papers could focus on the analysis of the benefits and difficulties of CE in a given supply chain, to understand the process of transition from linear economy to $C E$, and what were the changes and business models used. Thus, analyzing CE through a supply chain, the latter could be the source of studies to be replicated, researched, and analyzed in other chains. Analyzing the differences and similarities between the concepts of green supply chain management and CE is also an option, since many of the articles in the sample mentioned green supply chain management. Thus, a study could be done looking into how they complement each other, how they differ and how they are conceptualized by different authors, among other analyses.

Further alternatives would be analyzing the different types of business models based on CE used in different supply chains, how these models could help the development of chain members, their similarities, what are the major differences between a linear model and a circular business model, among other topics. Finally, another suggestion would be to analyze the social impact of circular economy, although not only from the environmental perspective, as observed in current practices.

\section{ACKNOWLEDGEMENTS}

The authors gratefully acknowledge the financial support of the Brazilian research funding agencies CNPq, FUNCAP and UFCA. 


\section{REFERENCES}

Abadia, L.G., Galvão, G.D.A. and Carvalho, M.M.D. (2016), "Economia circular: um estudo bibliométrico", in ENEGEP 2016: Contribuições da Engenharia de Produção para Melhores Práticas de Gestão e Modernização do Brasil, ABREPRO, João Pessoa.

Alvarado, R.U. (1984), "A bibliometria no Brasil", Ciência da Informação, Vol. 13, No. 2, pp. 91-105.

Ballou, R.H. (2006), Gerenciamento da cadeia de suprimentos: logística empresarial, Bookman Editora, São Paulo.

Barbieri, J.C., Sousa Filho, J.M., Brandão, C.N. et al. (2014), "Gestão verde da cadeia de suprimentos: análise da produção acadêmica brasileira", Revista Produção Online, Vol. 14, No. 3, pp. 1104-28. http://dx.doi.org/10.14488/1676-1901.v14i3.1674.

Bey, N., Hauschild, M.Z. and McAloone, T.C. (2013), "Drivers and barriers for implementation of environmental strategies in manufacturing companies", CIRP Annals, Vol. 62, No. 1, pp. 43-6. http://dx.doi.org/10.1016/j.cirp.2013.03.001.

Bilitewski, B. (2012), "The circular economy and its risks", Waste Management, Vol. 1, No. 32, pp. 1-2. http://dx.doi.org/10.1016/j.wasman.2011.10.004. PMid:22055527.

Bocken, N.M.P. (2015), “Conceptual framework for shared value creation based on value mapping”, in Global Cleaner Production Conference, Sitges, Barcelona.

Bocken, N.M.P., de Pauw, I., Bakker, C. et al. (2016), "Product design and business model strategies for a circular economy", Journal of Industrial and Production Engineering, Vol. 33, No. 5, pp. 308-20. http://dx.doi.org/10.1080/21681015.2016.1172124.

Botsman, R. and Rogers, R. (2009). O que é meu é seu: como o consumo colaborativo vai mudar o nosso mundo, Bookman Editora, São Paulo.

Bonciu, F. and Bâlgăr, A.C. (2016), "Sharing economy as a contributor to sustainable growth, An EU perspective", Romanian Journal of European Affairs, Vol. 16, No. 2, pp. 36-45.

Centobelli, P., Cerchione, R., Chiaroni, D. et al. (2020), "Designing business models in circular economy: A systematic literature review and research agenda", Business Strategy and the Environment, Vol. 29, No. 4, pp. 1734-49. http://dx.doi.org/10.1002/bse.2466.

Christopher, M. (1997), Logística e gerenciamento da cadeia de suprimentos: estratégias para a redução de custos e melhoria dos serviços, Pioneira, São Paulo.

Chopra, S. and Meindl, P. (2003), Gerenciamento da Cadeia de Suprimentos: estratégia, planejamento e operação, Prentice Hall, São Paulo.

Crossan, M.M. and Apaydin, M. (2010), "A multi-dimensional framework of organizational innovation: a systematic review of the literature", Journal of Management Studies, Vol. 47, No. 6, pp. 1154-91. http://dx.doi.org/10.1111/j.1467-6486.2009.00880.x.

Elia, V., Gnoni, M.G. and Tornese, F. (2017), "Measuring circular economy strategies through index methods: A critical analysis", Journal of Cleaner Production, Vol. 142, pp. 2741-51. http://dx.doi.org/10.1016/j.jclepro.2016.10.196.

Ellen MacArthur Foundation (2013), Towards the circular economy, Ellen MacArthur Foundation, United Kingdom.

Ellen MacArthur Foundation (2015), Rumo à economia circular: o racional de negócio para acelerar a transição. Ellen MacArthur Foundation, United Kingdom, available at: https://bityli.com/uLyNW (accessed 09 October 2020)

Geissdoerfer, M., Savaget, P., Bocken, N.M. et al. (2017), "The Circular Economy - A new sustainability paradigm", Journal of Cleaner Production, Vol. 143, pp. 757-68. http://dx.doi.org/10.1016/j.jclepro.2016.12.048.

Geng, Y. and Doberstein, B. (2008), "Developing the circular economy in China: Challenges and opportunities for achieving'leapfrog development", International Journal of Sustainable Development and World Ecology, Vol. 15, No. 3, pp. 231-9. http://dx.doi.org/10.3843/SusDev.15.3:6.

Genovese, A., Acquaye, A.A., Figueroa, A. et al. (2017), "Sustainable supply chain management and the transition towards a circular economy: Evidence and some applications", Omega, Vol. 66, pp. 344-57. http://dx.doi.org/10.1016/j.omega.2015.05.015.

Geissdoerfer, M., Pieroni, M.P.P., Pigosso, D.C.A. et al. (2020), "Circular business models: A review", Journal of Cleaner Production, Vol. 277, pp. 123741. http://dx.doi.org/10.1016/j.jclepro.2020.123741. 
Homrich, A.S., Galvao, G., Abadia, L.G. et al. (2018), "The circular economy umbrella: Trends and gaps on integrating pathways", Journal of Cleaner Production, Vol. 175, pp. 525-43. http://dx.doi.org/10.1016/j.jclepro.2017.11.064.

Humphrey, J. and Memedovic, O. (2006), Global Value Chains in the Agrifood Sector. United Nations, Industrial Development Organization, Vienna, Austria.

lizuka, E.S. and Peçanha, R.S. (2014), "Análise da produção cientifica brasileira sobre sustentabilidade entre 2008 e 2011", Revista de Gestão Ambiental e Sustentabilidade, Vol. 3, No. 1, pp. 1-17. http://dx.doi.org/10.5585/geas.v3i1.80.

Lambert, D.M., Stock, J.R. and Ellram, L.M. (1998), Fundamentals of logistics management, McGraw-Hill, Irwin.

Littell, J.H., Corcoran, J. and Pillai, V. (2008), Systematic reviews and meta-analyses. Oxford Univerty Press, New York. http://dx.doi.org/10.1093/acprof:oso/9780195326543.001.0001.

Locke, K. and Golden-Biddle, K. (1997), "Constructing opportunities for contribution: Structuring intertextual coherence and "problematizing" in organizational studies", Academy of Management Journal, Vol. 40, No. 5, pp. 1023-62. http://dx.doi.org/10.5465/256926.

McDonough, W., and Braungart, M. (2010), Cradle to cradle: Remaking the way we make things, North Point Press, New York, NY.

Merli, R., Preziosi, M. and Acampora, A. (2018), "How do scholars approach the circular economy? A systematic literature review", Journal of Cleaner Production, Vol. 178, pp. 703-22. http://dx.doi.org/10.1016/j.jclepro.2017.12.112.

Murray, A., Skene, K. and Haynes, K. (2017), "The circular economy: An interdisciplinary exploration of the concept and application in a global context", Journal of Business Ethics, Vol. 140, No. 3, pp. 369-80. http://dx.doi.org/10.1007/s10551-015-2693-2.

Nasir, M.H.A., Genovese, A., Acquaye, A.A. et al. (2017), "Comparing linear and circular supply chains: A case study from the construction industry", International Journal of Production Economics, Vol. 183, pp. 443-57. http://dx.doi.org/10.1016/j.ijpe.2016.06.008.

Niero, M., Negrelli, A.J., Hoffmeyer, S.B. et al. (2016), "Closing the loop for aluminum cans: Life Cycle Assessment of progression in Cradle-to-Cradle certification levels", Journal of Cleaner Production, Vol. 126, pp. 352-62. http://dx.doi.org/10.1016/j.jclepro.2016.02.122.

Park, J., Sarkis, J. and Wu, Z. (2010), "Creating integrated business and environmental value within the context of China's circular economy and ecological modernization", Journal of Cleaner Production, Vol. 18, No. 15, pp. 1494-501. http://dx.doi.org/10.1016/j.jclepro.2010.06.001.

Pauli, G.A. (2010), The blue economy: 10 years, 100 innovations, 100 million jobs, Paradigm Publications, New Mexico.

Prugh, T. and Assadourian, E. (2003), "What is sustainability, anyway", World Watch, Vol. 16, No. 5, pp. 10-21.

Research Guides (2018), Measuring your impact: Impact factor, citation analysis, and other metrics, University of Illinois, Chicago, available at:https://researchguides.uic.edu/if/impact (accessed 09 October 2020).

Ribeiro, F.D.M. and Kruglianskas, I. (2014), "Economia Circular no contexto europeu: Conceito e potenciais de contribuição na modernização das políticas de resíduos sólidos", in ENGEMA: XVI Encontro Internacional sobre Gestão Empresarial e Meio Ambiente, São Paulo.

Sehnem, S. and Pereira, S.C.F. (2019), "Rumo à economia circular: sinergia existente entre as definições conceituais correlatas e apropriação para a literatura brasileira", Revista Eletrônica de Ciência Administrativa, Vol. 18, No. 1, pp. 35-62. http://dx.doi.org/10.21529/RECADM.2019002.

Silva, M.E. and Cândido, G.A. (2014), "The business contribution for sustainable consumption: a proposal of theoretical categories and analytical parameters", Revista Eletrônica de Ciência Administrativa, Vol. 13, No. 1, pp. 74-88. http://dx.doi.org/10.21529/RECADM.2014004.

Scopus (2018), "About Scopus", available at: https://www.elsevier.com/solutions/scopus (accessed 09 October 2020).

Schwab, K. (2014), "The Global Competitiveness Report 2014-2015", World Economic Forum, Geneve.

Srivastava, S.K. (2007), "Green supply-chain management: a state-of-the-art literature review", International Journal of Management Reviews, Vol. 9, No. 1, pp. 53-80. http://dx.doi.org/10.1111/j.14682370.2007.00202.x. 
Su, B., Heshmati, A., Geng, Y. et al. (2013), "A review of the circular economy in China: moving from rhetoric to implementation", Journal of Cleaner Production, Vol. 42, pp. 215-27. http://dx.doi.org/10.1016/j.jclepro.2012.11.020.

Tranfield, D., Denyer, D. and Smart, P. (2003), "Towards a methodology for developing evidence-informed management knowledge by means of systematic review", British Journal of Management, Vol. 14, No. 3, pp. 207-22. http://dx.doi.org/10.1111/1467-8551.00375.

Torres Junior, A.S. and Parini, F.P. (2017). Economia circular: evolução e perspectiva inovadora, São Paulo: EAD/FEA/USP.

Ünal, E., Urbinati, A., Chiaroni, D. et al. (2019), "Value Creation in Circular Business Models: The case of a US small medium enterprise in the building sector", Resources, Conservation and Recycling, Vol. 146, pp. 291-307. http://dx.doi.org/10.1016/j.resconrec.2018.12.034.

van Eck, N. and Waltman, L. (2010), "Software survey: VOSviewer, a computer program for bibliometricnmapping", Scientometrics, Vol. 84, No. 2, pp. 523-38. http://dx.doi.org/10.1007/s11192009-0146-3. PMid:20585380.

Vosviewer (2019), "About VosViewer", available at: http://www.vosviewer.com/ (accessed 09 October 2020).

Winkler, H. (2011), "Closed-loop production systems-A sustainable supply chain approach", CIRP Journal of Manufacturing Science and Technology, Vol. 4, No. 3, pp. 243-6. http://dx.doi.org/10.1016/j.cirpj.2011.05.001.

Zhu, Q., Geng, Y. and Lai, K. (2010), "Circular economy practices among Chinese manufacturers varying in environmental-oriented supply chain cooperation and the performance implications", Journal of Environmental Management, Vol. 91, No. 6, pp. 1324-31. http://dx.doi.org/10.1016/j.jenvman.2010.02.013. PMid:20223586.

Zhu, Q., Geng, Y. and Lai, K. (2011), "Environmental supply chain cooperation and its effect on the circular economy practice-performance relationship among Chinese manufacturers", Journal of Industrial Ecology, Vol. 15, No. 3, pp. 405-19. http://dx.doi.org/10.1111/j.1530-9290.2011.00329.x.

Author contributions: Renan Pereira: data collecting and writing; Edivan Alexandre Ferreira: data collecting, writing and revision; Josivan Leite Alves: data collecting, writing and revision; Jeniffer de Nadae: managing the project; Graziela Darla Araujo Galvão: managing the project. 